\title{
Biogenic silica as an estimate of siliceous microfossil abundance in Great Lakes sediments
}

\section{DANIEL J. CONLEY}

Great Lakes Research Division, The University of Michigan, Ann Arbor, MI 48109, USA: (present address: Department of Fisheries and Aquaculture, University of Florida, 7922 NW 71st Street, Gainesville, FL 32606, USA)

Key words: biogenic silica, diatoms, Great Lakes, sediments

\begin{abstract}
Biogenic silica concentration (BSi) in sediment cores from the Great Lakes is evaluated as an estimate of siliceous microfossil abundance. A significant linear relationship was found between measured $\mathrm{BSi}$ and diatom valve abundance for sediment cores from the Bay of Quinte, Lake Ontario, Lake Erie, Lake Michigan and Lake Superior and between measured BSi and diatom biovolume for Lake Erie, Lake Michigan, and Lake Superior but not for Lake Ontario. Diatom silica predicted from diatom species abundance and an estimated silica content per cell in the Lake Erie cores accounted for $117 \%$ and $103 \%$ of measured BSi, respectively. By contrast, predicted diatom silica could only account for $28 \%$ of measured BSi in the Lake Michigan core and only $25 \%$ in the Lake Superior core. A few large diatoms with a large silica content per cell comprised a major portion of predicted diatom silica in all cores. The discrepancy between chemically measured BSi and the silica predicted from diatoms in the Lake Michigan and Lake Superior cores was partially due to the inability of the regression model, used to estimate diatom silica content, to account for different degrees of silicification in the diatom asemblages from the more dissolved silica rich Lake Michigan and Lake Superior.
\end{abstract}

\section{Introduction}

The stratigraphy of biological and chemical components in sediments provides a wealth of information which allows reconstruction of the history of lakes and oceans. Biogenic silica (BSi), an amorphous form of silicon biogenically precipitated by a variety of siliceous organisms (diatoms, silicoflagellates, radiolarians, and sponges), is a component of sediments commonly determined in paleolimnological and paleoceanographic studies. The ease of determining BSi in comparison to the laborious task of enumerating siliceous microfossils has led to its use as an indicator of siliceous microfossil abundance in sediments. 
Variations in BSi concentration in marine sediments are generally used to infer productivity of overlying waters (Lisitsyn 1971). In paleolimnological studies, however, using BSi stratigraphies in reconstructing historical lake productivities have met with limited success (Digerfeldt 1972; Engstrom \& Wright 1984; Newberry \& Schelske 1986). Relating sedimentary BSi to paleoproductivity requires that:

- BSi preserved in sediments is representative of overlying water productivity.

- There have been no changes in BSi preservation over the time interval of interest.

- Depletion of dissolved silica in the water has not reduced BSi inputs to sediments (Schelske et al. 1983) while non-siliceous forms of algae experience increased levels of production (Schelske \& Stoermer 1971).

- Mass sedimentation rates can be measured so that BSi fluxes to the sediment can be determined.

Although BSi concentrations in sediments generally reflect siliceous microfossil abundance (Renberg 1976; Schelske et al. 1983; Newberry \& Schelske 1986), concerns have been raised whether chemical or physical techniques used to measure BSi are in fact determining microfossil silica or other forms of amorphous silica (Robbins et al. 1975). The use of BSi as an indicator of paleoproductivity, therefore, has been limited because of these uncertainties.

Numerous limnological studies have shown that diatoms modify dissolved silica concentrations in natural waters through the uptake of dissolved silica and incorporation into their frustule as BSi (Lund 1950; Kilham 1971; Schelske \& Stoermer 1971). Furthermore, calculation of the amount of dissolved silica removed from the water column has been estimated from the amount of dissolved silica utilized by individual diatom species (Gibson et al. 1971; Cheng \& Tyler 1973; Bailey-Watts 1976; Gibson 1981; Sommer \& Stabel 1983). By contrast, sediment studies have not been successful in accounting for measured BSi from that calculated from microfossil abundance (Robbins et al. 1975; Boucher 1984; Leinen 1985).

The purpose of the present study is to determine how well chemical measurements of BSi concentration reflect siliceous microfossil abundance in five cores from the Great Lakes. Regression models were used to determine the relationship between BSi and diatom abundance. BSi was predicted by summing the estimated silica content of species in the diatom assemblage present in cores and was then compared with measured BSi in cores. Factors that contribute to variation in the relationship between measured BSi in cores and diatom abundance are discussed. 


\section{Methods}

\section{Microfossil counts}

Microfossil assemblages in sediment cores from the Bay of Quinte (Stoermer et al. 1985a), Lake Ontario (Stoermer et al. 1985b), Lake Erie (Stoermer et al. 1987), Lake Superior (Stoermer et al. 1985c) and Lake Michigan (E.F. Stoermer \& J.A. Wolin unpubl. data) were enumerated in the laboratory of Dr. E.F. Stoermer (Great Lakes Research Division, University of Michigan, Ann Arbor, Michigan, USA).

Quantitative estimates of siliceous microfossil abundance were made using a modification of the settling chamber technique originally developed by Battarbee (1973), (see Stoermer et al. 1985a for details). All fragments were identified to the lowest taxonomic category possible and the fragments were reconstituted into whole valves by summing the fractional categories. The reconstitution of fragments into whole valves allows for the assumption that the contribution of unmeasured diatom fragments to BSi will be negligible.

\section{Biogenic silica}

Different techniques have been used to determine the concentration of biogenic silica (BSi) or opal in sediments (see DeMaster 1981; Leinen 1985). The method used in this study was the wet chemical dissolution technique utilizing a weak $\mathrm{Na}_{2} \mathrm{CO}_{3}$ base to dissolve $\mathrm{BSi}$ in a sediment matrix (Hurd 1972; Eggimann et al. 1980; DeMaster 1981). It is based on the fact that the poorly crystalline silica of microfossils dissolves readily in a weak base such that $\mathrm{BSi}$ is essentially dissolved in $2 \mathrm{~h}$ and that the more ordered mineral phases dissolve at a much slower and constant rate. By measuring over time the increase in dissolved silica concentrations from sediments during the digestion and then extrapolating back to time zero, i.e. the intercept, the silica extracted can be corrected for the dissolution of mineral silica (DeMaster 1981).

Freeze-dried sediment was digested in $1 \% \mathrm{Na}_{2} \mathrm{CO}_{3}$ for $4 \mathrm{~h}$ at $85^{\circ} \mathrm{C}$. Sub-samples were removed at 2,3, and $4 \mathrm{~h}$ and analyzed for dissolved silica on a Technicon AutoAnalyzer II. BSi concentrations were determined from a least squares regresion of the amount of dissolved silica extracted from the sediment vs time. The error associated with the measurement of BSi was generally $\pm 10 \%$.

BSi concentrations in sediments from the Bay of Quinte (Schelske et al. 
1985), Lake Ontario (Schelske et al. 1983), Lake Erie (Schelske et al. 1986), Lake Superior (Stoermer et al. 1985c), and Lake Michigan (Schelske et al. 1986) were published previously.

BSi concentrations also were determined on freeze-dried sediment that had been digested in $10 \% \mathrm{HCl}$ for $1 \mathrm{~h}$ at $90^{\circ} \mathrm{C}$ and subjected to additions of $30 \% \mathrm{H}_{2} \mathrm{O}_{2}$ until vigorous bubbling had ceased. After digestion the sediment was filtered onto $0.45 \mu \mathrm{m}$ Nuclepore polycarbonate filters, washed several times to remove all traces of acid and digested for BSi.

\section{Silica content of diatoms}

The silica content of diatoms reported in the literature varies greatly because of the variety of techniques used to determine silica cell content, differences in the degree of silicification of populations from other localities, and differences in the size of species between localities. Diatom silica content can be estimated from the size of a cell because the amount of silica incorporated into a diatom should be proportional to its size. Biovolume estimates have been used to provide first-order estimates such as carbon (Strathmann 1967) or, in this case, silica (Conley et al., submitted). Least square regression

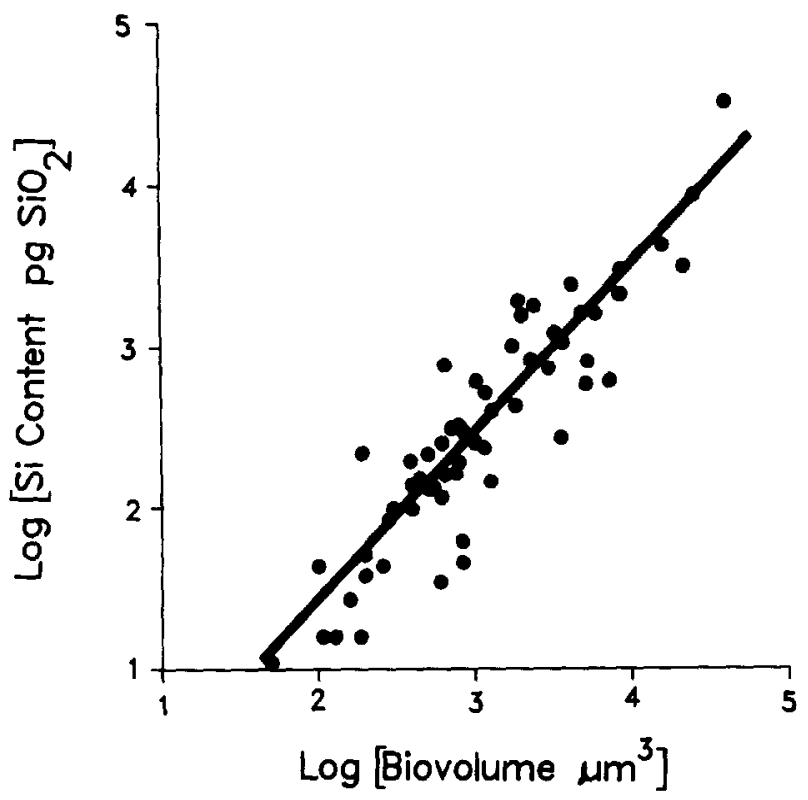

Fig. 1. Biovolume vs silica content of diatoms. Redrawn from Conley et al. (submitted). 
analysis was used to predict the approximate silica content of a diatom species from its biovolume (Fig. 1) by the following equation (Conley et al., submitted):

$$
\begin{aligned}
& \log _{10}[\text { silica content }]=(1.03 \pm 0.06) \log _{10}[\text { biovolume }]-(0.67 \pm 0.19) \\
& \left(n=62, \mathrm{r}^{2}=0.83, p<0.0001\right)
\end{aligned}
$$

If biovolume of a species is known or can be determined, one can estimate its silica content.

Data on biovolume of Great Lakes diatom species were available from earlier studies (T.B. Ladewski \& E.F. Stoermer, Great Lakes Research Division, University of Michigan, Ann Arbor, Michigan, USA, unpubl. data). When a biovolume was not available, it was determined by measuring valve dimensions from select intervals in cores and using the best geometric approximation to calculate biovolume.

\section{Prediction of $B S i$}

BSi was predicted ( $\mathrm{pBSi}$ ) from diatom abundance by summing the amount of silica estimated in the diatom assemblage in a core. BSi in a sediment interval was calculated by multiplying valve concentration of species $i, V_{i}$, divided by two valves per cell, times the estimated silica content of a diatom per cell determined from its biovolume of species $\mathrm{i}, \mathrm{Si}_{\mathrm{i}}$. The quantity of silica from species in that interval were then summed to obtain, pBSi, i.e.

$$
\mathrm{pBSi}=\sum_{\mathrm{i}=1, \mathrm{n}}^{\mathrm{n}} \frac{\mathrm{V}_{\mathrm{i}}}{2} \mathrm{Si}_{\mathrm{i}}
$$

pBSi was not calculated for the Bay of Quinte because species composition was considerably different from that in the other cores studied.

Because diatoms were the major component of siliceous microfossils in cores, data from chrysophycean cysts and sponge spicules were not included in the calculation of $\mathrm{pBSi}$. In addition, because of the large number of species found in cores, not all species were used in the analysis. Only species which comprised at least $5 \%$ of total abundance or appeared in at least $25 \%$ of the intervals in a core were used in the calculation of pBSi. Therefore, only $67 \%$ of the assemblage counted was used in the calculating pBSi in the Lake Ontario core, $94 \%$ in the Lake Erie core, $74 \%$ in the Lake Michigan core, and $71 \%$ in the Lake Superior core. 


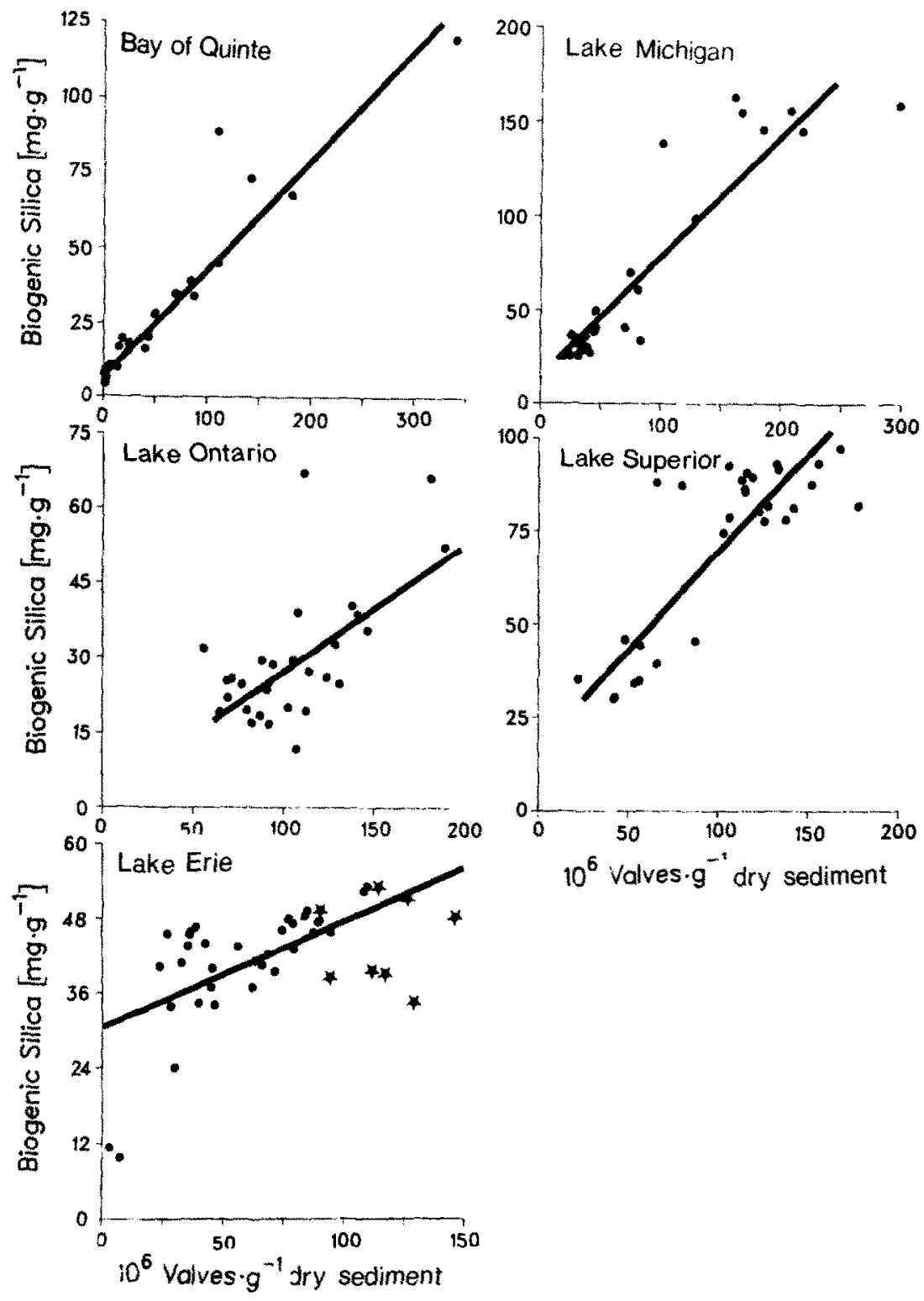

Fig. 2. Valve concentration vs BSi concentration in cores. The stars in the Lake Erie core denote intervals in which large numbers of the diatom Stephanodiscus parvus are present.

\section{Results}

Comparison of BSi to diatom abundance and biovolume

A significant linear relationship between valve concentration and measured BSi was found for cores in each lake (Fig. 2, Table 1). A significant linear 
Table 1. Results of least squares regression analysis.

\begin{tabular}{|c|c|c|c|c|}
\hline \multirow[t]{2}{*}{ Lake } & \multirow[t]{2}{*}{ (n) } & \multicolumn{2}{|c|}{ Regression coefficients } & \multirow[t]{2}{*}{$r^{2}$} \\
\hline & & Intercept & Slope & \\
\hline \multicolumn{5}{|c|}{ Valve abundance vs measured Bsi } \\
\hline Bay of Quinte & 36 & 7.84 & 0.365 & $0.91^{* *}$ \\
\hline Lake Ontario & 30 & 2.37 & 0.259 & $0.40^{* *}$ \\
\hline Lake Erie & 43 & 30.90 & 0.152 & $0.33^{* *}$ \\
\hline Lake Michigan & 36 & 13.10 & 0.656 & $0.86^{* *}$ \\
\hline Lake Superior & 30 & 24.10 & 0.460 & 0.67 ** \\
\hline Combined data & 175 & 11.60 & 0.435 & $0.56^{* *}$ \\
\hline \multicolumn{5}{|c|}{ Biovolume vs measured Bsi } \\
\hline Lake Ontario & 30 & 19.8 & $0.96 \times 10^{-4}$ & $0.07^{\mathrm{NS}}$ \\
\hline Lake Erie & 43 & 19.6 & $0.15 \times 10^{-3}$ & $0.62 * *$ \\
\hline Lake Michigan & 36 & 16.6 & $0.86 \times 10^{-3}$ & $0.76^{* *}$ \\
\hline Lake Superior & 30 & 26.9 & $0.85 \times 10^{-3}$ & $0.68 * *$ \\
\hline
\end{tabular}

** Significant at $p<0.01 ;{ }^{\text {NS }}$ Not significant.

relationship between valve concentration and measured BSi was also attained when the data from all cores were combined (Table 1), although the scatter was large (Fig. 3). The regression between total assemblage biovolume and measured BSi was significant for cores from Lake Erie, Lake

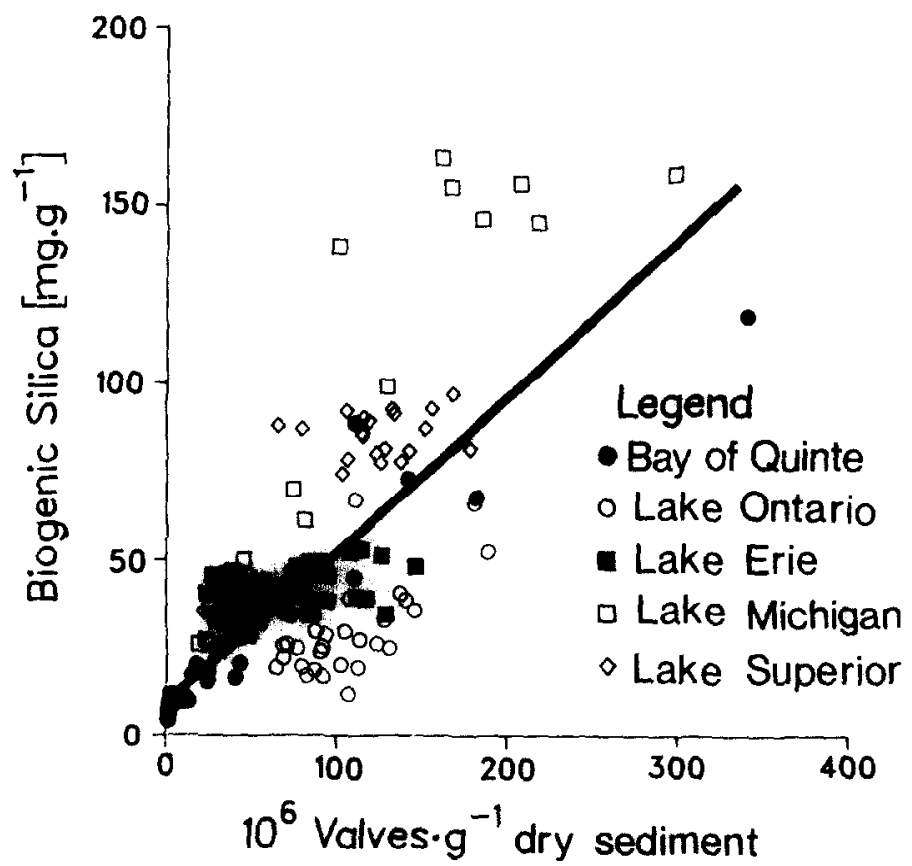

Fig. 3. Valve concentration vs BSi concentration for combined data from the cores studied. 
Table 2. Calculated mean silica content of diatoms, mean biovolume per cell, and ratio of calculated mean silica content to mean biovolume $\left(\mathrm{SiO}_{2}: \mathrm{BV}\right)$.

\begin{tabular}{llll}
\hline Lake & $\begin{array}{l}\text { Mean silica content } \\
\left(\mathrm{pg} \mathrm{SiO}_{2} \cdot \text { cell }^{-1}\right)\end{array}$ & $\begin{array}{l}\text { Mean biovolume } \\
\left(\mu \mathrm{m}^{3} \cdot \mathrm{cell}^{-1}\right)\end{array}$ & $\begin{array}{l}\mathrm{SiO}_{2}: \mathrm{BV} \\
\left.(\mathrm{pg} \mathrm{SiO})_{2} \cdot \mu \mathrm{m}^{-3}\right)\end{array}$ \\
\hline $\begin{array}{l}\text { Bay of Quinte } \\
\text { Presettlement }\end{array}$ & $\begin{array}{l}4670 \pm 4110 \\
\text { Postsettlement }\end{array}$ & $1330 \pm 662$ & \\
Lake Ontario & $576 \pm 209$ & $1940 \pm 446$ & 0.300 \\
Lake Erie & $1640 \pm 1200$ & $4850 \pm 1450$ & 0.338 \\
$\quad 0-8 \mathrm{~cm}$ & $1060 \pm 360$ & $3950 \pm 1230$ & 0.267 \\
$8-20 \mathrm{~cm}$ & $1200 \pm 230$ & $4710 \pm 1150$ & 0.255 \\
$20-38 \mathrm{~cm}$ & $2410 \pm 618$ & $6190 \pm 1200$ & 0.390 \\
Lake Michigan & $1870 \pm 456$ & $1450 \pm 262$ & 1.29 \\
Lake Superior & $1490 \pm 474$ & $1010 \pm 220$ & 1.48 \\
\hline
\end{tabular}

Michigan and Lake Superior, but not for Lake Ontario (Table 1). Using diatom biovolume instead of valve abundance improved the relationship only in the Lake Erie core.

If all measured BSi in cores can be attributed to diatoms than a mean silica content of a diatom assemblage can be calculated by dividing measured BSi by diatom abundance. Differences in calculated mean silica content were found both downcore (Figs. 4-8) and between lakes (Table 2). Calculated mean diatom silica content in Bay of Quinte sediments (Fig. 4) abruptly decreased by a factor of six after 1850 following settlement of the

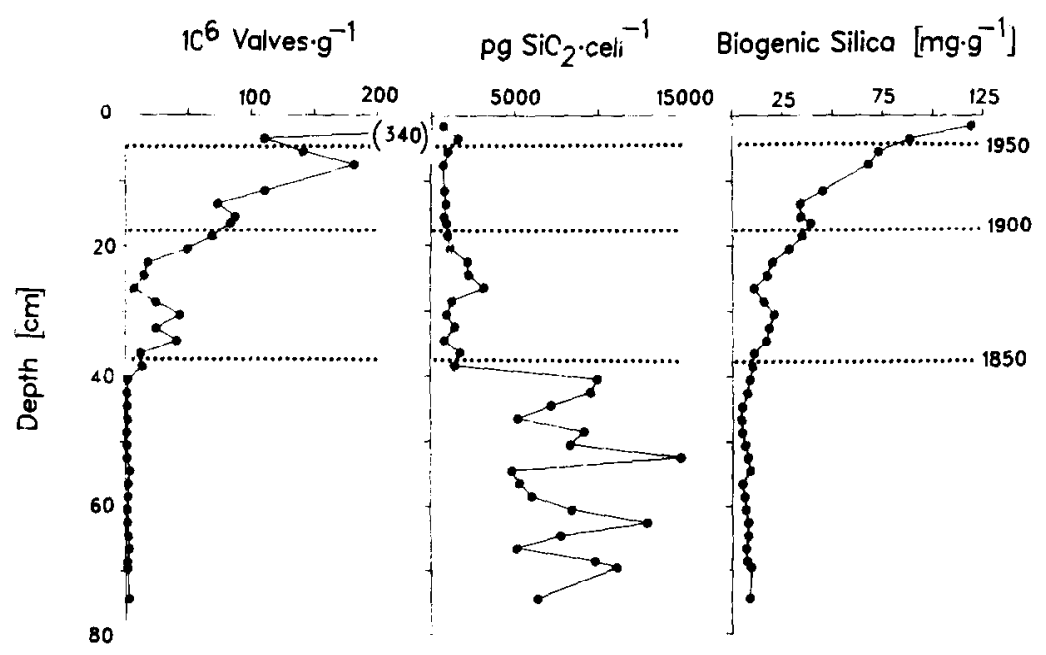

Fig. 4. Valve concentration, calculated diatom silica per cell and BSi concentration from the Bay of Quinte core. Dates taken from Schelske et al. (1985). 
basin. However, this change is probably the result of the presence of sponge spicules, which can contain an order of magnitude more silica than diatoms (Boucher 1984). Sponge spicules comprised on the average $25 \%$ of the presettlement siliceous microfossils in the Bay of Quinte (Stoermer et al. 1985a). By contrast, following settlement of the Bay of Quinte basin sponge spicules comprised on the average only $0.7 \%$ of the presettlement siliceous microfossils. In Lake Erie, calculated mean diatom silica content also decreased upcore (Fig. 6). Cores from Lake Michigan (Fig. 7) and Lake Superior (Fig. 8) had no consistent trend in calculated mean diatom silica content with depth.

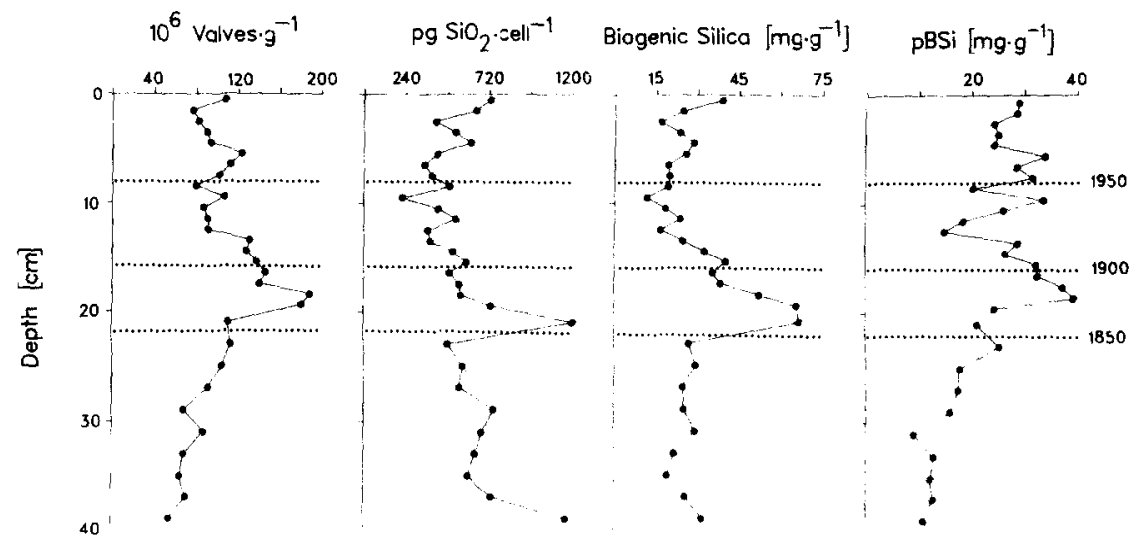

Fig. 5. Valve concentration, calculated diatom silica per cell, BSi concentration and calculated pBSi from the Lake Ontario core. Dates taken from Schelske et al. (1983).

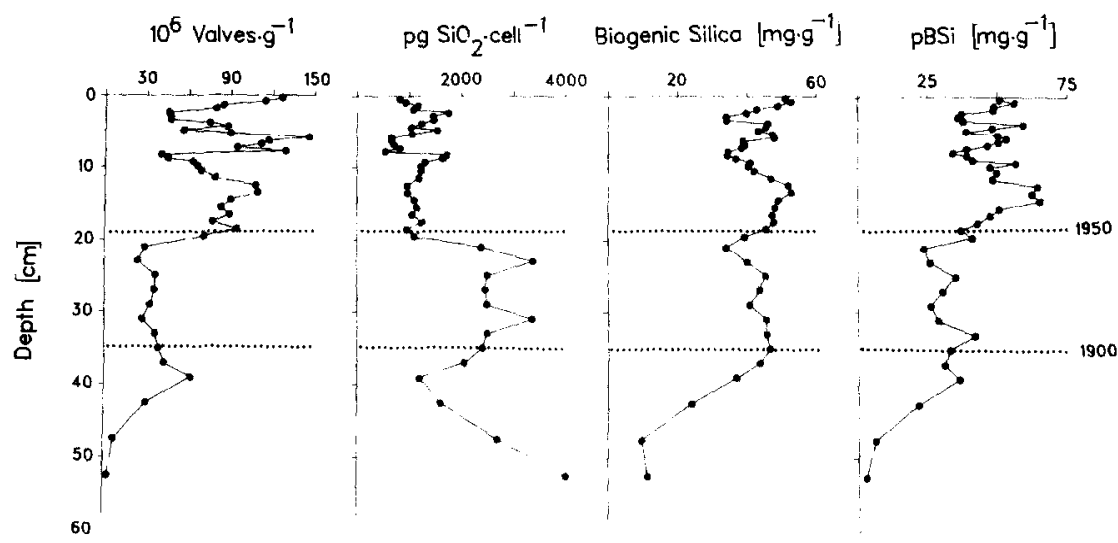

Fïg. 6. Valve concentration, calculated diatom silica per cell, BSi concentration and calculated pBSi from the Lake Erie core. Dates taken from Stoermer et al. (1987). 
The silica content of diatoms predicted from biovolume provides a good first-order estimate of the amount of silica in a diatom. However, the model (Eq. 1) has a $95 \%$ confidence interval of $56-180 \%$ of the calculated silica content of a diatom for a given biovolume. The estimation of silica content from the least squares regression analysis was insensitive to silicification of different species. For example, Sicko-Goad et al. (1984) determined that the biovolume of Melosira granulata was $5127 \mu \mathrm{m}^{3}$ and had a silica content of $581 \mathrm{pg} \mathrm{SiO}{ }^{2} \cdot \mathrm{cell}^{-1}$. By contrast, Melosira islandica has a biovolume one third that of $M$. granulata, but is almost twice as heavily silicified containing $1059 \mathrm{pg} \mathrm{SiO}{ }_{2} \cdot \mathrm{cell}^{-1}$. Because silica content was predicted from biovolume, the regression analysis predicted a greater silica content in $M$. granulata than in $M$. islandica. Another example of the inability of the regression model to differentiate silicification may be found in the Stephanodiscus niagarae complex. Stephanodiscus superiorensis, a diatom found only in Lake Superior (Theriot \& Stoermer 1984), overlaps the size range and biovolume of $S$. niagarae. However, it is approximately twice as heavily silicified as $S$. niagarae (Theriot \& Stoermer 1984), which could not be accounted for by the regression model used in this study. Frustule thickness, which would allow for a different amount of silicification, would clearly be a better predictor of silica content. However, frustule thickness measurements are not only lacking for most species, but also are difficult measurements to make on diatoms.

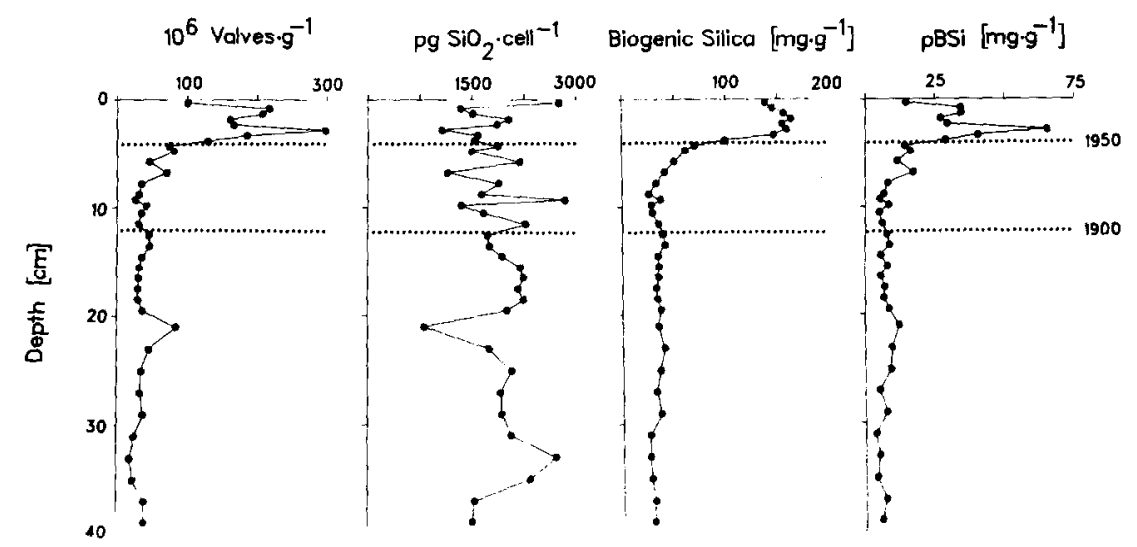

Fig. 7. Valve concentration, calculated diatom silica per cell, BSi concentration and calculated pBSi from the Lake Michigan core. Dates from T.L. Newberry \& C.L. Schelske (Great Lakes Research Division, University of Michigan, Ann Arbor, Michigan, USA, unpub. data). 


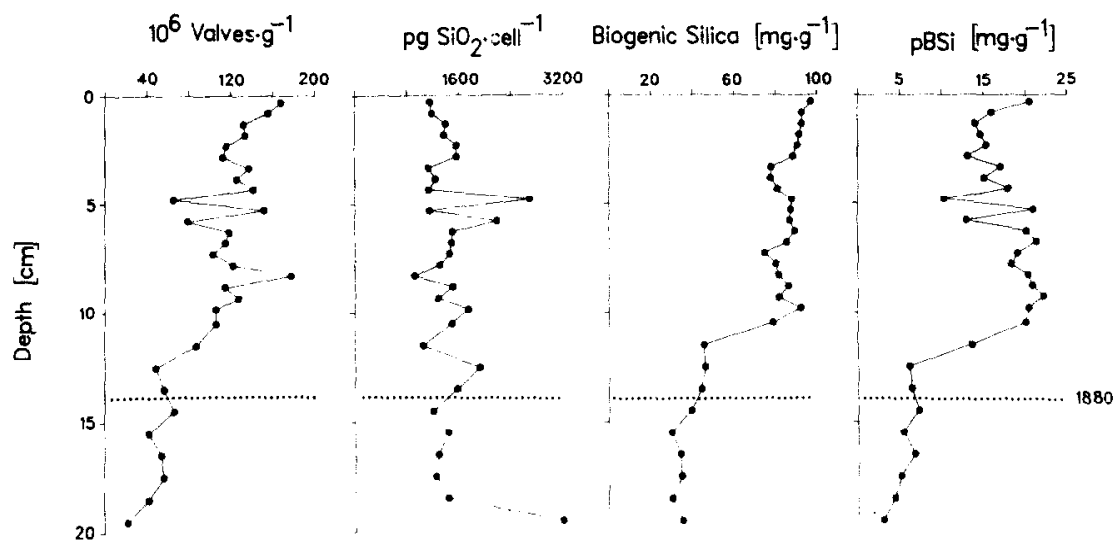

Fig. 8. Valve concentration, calculated diatom silica per cell, BSi concentration and calculated pBSi from the Lake Superior core. Settlement horizon from Stoermer et al. (1985c).

\section{Predicted BSi in cores}

Predicted BSi (pBSi) from cores generally understimated measured BSi (Figs. 5-8). pBSi calculated from species abundance and their respective silica content could account, on average, for $97 \%$ of BSi measured from the Lake Erie core, $91 \%$ in the Lake Ontario core, $23 \%$ in the Lake Michigan corc, and $22 \%$ in the Lake Superior core (Table 3). Because not all species enumerated in cores were used to calculate $\mathrm{pBSi}, \mathrm{pBSi}$ was adjusted to include the percentage of diatom assemblage not used in calculating $\mathrm{pBSi}$. The adjusted percentage of $\mathrm{pBSi}$ was $117 \%$ of measured $\mathrm{BSi}$ from the Lake Ontario core, $103 \%$ in the Lake Erie core, and $28 \%$ in the Lake Michigan core and $25 \%$ in the Lake Superior core (Table 3).

The largest diatoms with a high silica content per cell comprised the major portion of pBSi in all cores (Table 3). For example, in the Lake Erie core, $S$. niagarae averaged $18 \%$ of the diatom assemblage and comprised $82 \%$ of pBSi. By contrast, Stephanodiscus parvus was found in the Lake Erie core in almost equal abundance (15\% of the assemblage) but comprised only $0.2 \%$ of pBSi. Another example of a small population having a large influence on $\mathrm{pBSi}$ was found in the Lake Superior core where S. superiorensis was only $1 \%$ of the population yet comprised $18 \%$ of $\mathrm{pBSi}$. The presence of a few diatoms with a large silica content that accounted for the majority of $\mathrm{pBSi}$ was consistent throughout the cores examined (Table 3 ).

\section{Discussion}

The results presented here demonstrate that the silica content of the largest diatoms was the major factor affecting the amount of BSi chemically 
172

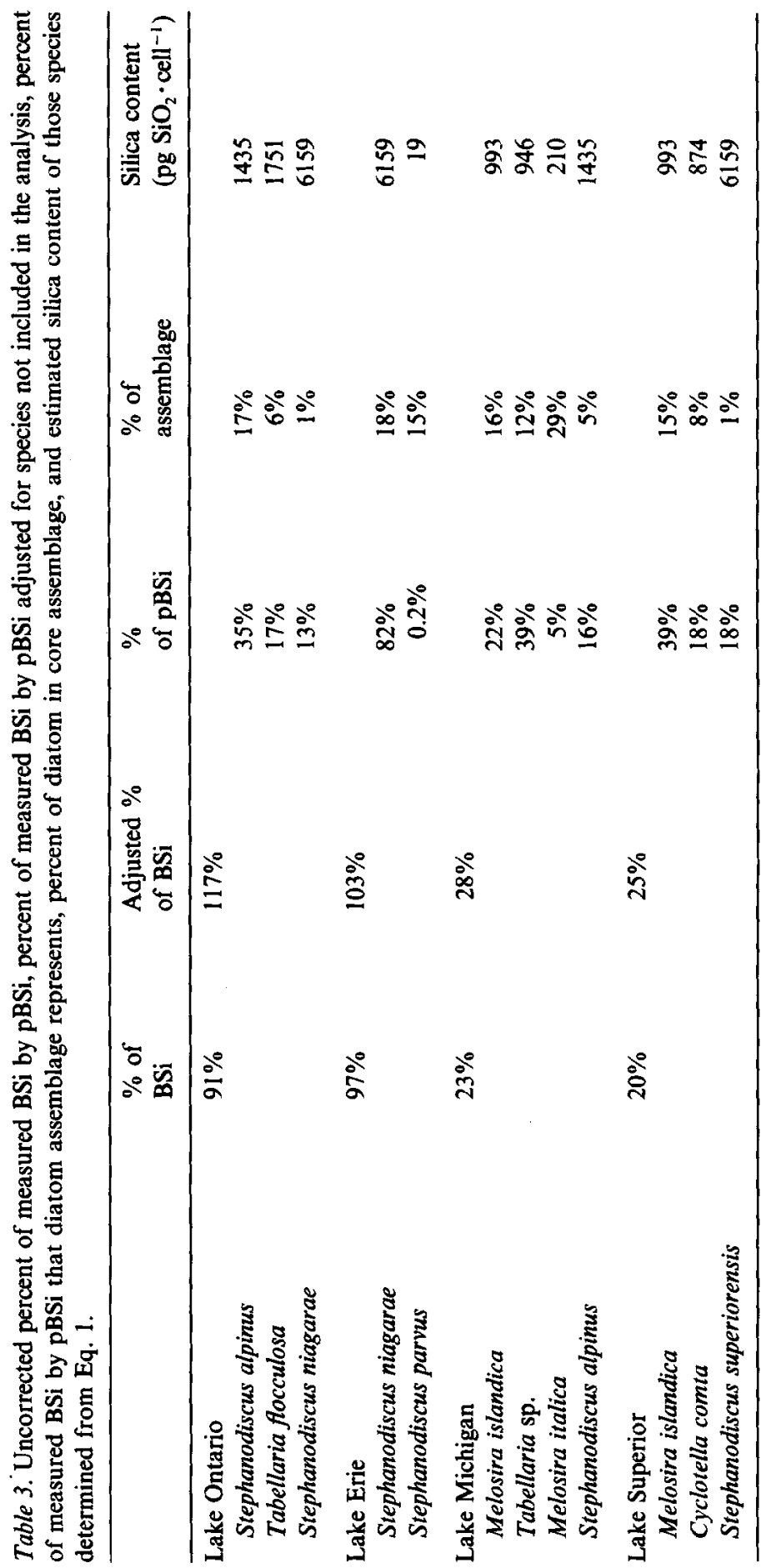


measured in cores. Because mean silica content of an assemblage will vary with species composition, changes in diatom community composition, therefore, will affect the correlation between diatom abundance and BSi. It is possible to adjust for changes in silica content by expressing the assemblage in terms of biovolume, which roughly takes into account differences in size structure of the assemblage. Of the cores analyzed (Table 1), however, only in the Lake Erie core, was an improvement noted in the correlation between biovolume and measured $\mathrm{BSi}$. Improvement of the correlation with BSi in the Lake Erie core occurred because biovolume corrected for the high abundance of the small diatom $S$. parvus present in the core (identified with stars in Fig. 2). Initial comparison suggests that improvement of the correlation with BSi using biovolume instead of valve concentration occurs only when there is a large range in diatom sizes and other studies support this hypothesis (Flower 1980; Newberry \& Schelske 1986).

Downcore changes found in calculated mean diatom silica content (Figs. 4-8) may be partially due to a change in size structure of the diatom asemblage and the accompanying change in silica content with cell size. The ratio of calculated mean diatom silica content to mean diatom biovolume (Table 2) normalizes for both abundance and biovolume changes downcore and also provides an estimate of silicification of the population. The calculated silica per unit biovolume of the diatom assemblage ranged from $0.300 \mathrm{pg} \mathrm{SiO}_{2} \cdot \mu \mathrm{m}^{-3}$ in the Lake Ontario core to $1.48 \mathrm{pg} \mathrm{SiO}_{2} \cdot \mu \mathrm{m}^{-3}$ in the Lake Superior core (Table 2). By comparison, freshwater diatoms from the literature survey in Fig. 1 contain on average $0.33 \mathrm{pg} \mathrm{SiO}_{2} \cdot \mu \mathrm{m}^{-3}$ (Conley et al., submitted) and values as high as $2.36 \mathrm{pg} \mathrm{SiO}_{2} \cdot \mu \mathrm{m}^{-3}$ have been reported for diatoms in other freshwaters (Einsele \& Grim 1938).

Silica per unit biovolume for diatom assemblages in cores appears to reflect disolved silica supplies in the water column. Lake Superior, being the most oligotrophic and dissolved silica rich of the Great Lakes (Schelske \& Roth 1973), had the most heavily silicified population, followed by Lake Michigan at $1.29 \mathrm{pg} \mathrm{SiO}_{2} \cdot \mu \mathrm{m}^{-3}$, which undergoes dissolved silica limitation during the stratified period (Schelske \& Stoermer 1971). Diatom assemblage silicification in the Lake Ontario core was a factor of five lower than in the core from Lake Superior. Lake Ontario has undergone severe nutrient enrichment with European settlement of the basin and probably has been dissolved silica limited for an exended period (Stoermer et al. 1985b). The $\mathrm{SiO}_{2}$ : Biovolume ratio of the diatom asemblage in the Lake Erie core declined stepwise as productivity increased (Stoermer et al. 1987). A decline in $\mathrm{SiO}_{2}$ : Biovolume ratio can occur by two mechanisms:

- A decline in silicification of species present as dissolved silica limitation becomes more intense with increased eutrophication. 
- A change in species composition with dissolved silica limitation, which selects for new species that have lower silica requirements.

In Lake Michigan and Lake Superior, adjusted pBSi was within a factor of four in predicting measured $\mathrm{BSi}$, and adjusted $\mathrm{pBSi}$ in Lake Ontario and Lake Erie overestimated measured BSi by $17 \%$ and 3\%, respectively. By comparison, in studies on marine sediments, Leinen (1985) could predict only $0.5-5 \%$ of total opal in a core calculated from radiolarian microfossil data, whereas Boucher (1984) was on the average within a factor of four in accounting for BSi from siliceous microfossil abundance. Robbins et al. (1975) could account for less than $10 \%$ of measured BSi in a core from Lake Michigan calculated from diatom abundance and an estimate of mean diatom silica content determined from a plankton tow. Use of plankton tows to obtain a mean diatom silica content can lead to an underestimation of the amount of BSi in sediments because not all species in tows are found in sediments (Haworth 1980), primarily due to loss of lightly silicified species from the sediment record (Glover 1982). Despite these limitations, the mean silica content determined by Parker \& Edgington (1976) from plankton tows in Lake Michigan, used in the Robbins et al. (1975) analysis, was $1140 \mathrm{pg}$ $\mathrm{SiO}_{2} \cdot$ cell $^{-1}$; only $39 \%$ lower than the estimated mean diatom silica content calculated in the Lake Michigan core $\left(1870 \mathrm{pg} \mathrm{SiO}_{2} \cdot\right.$ cell $\left.^{-1}\right)$ in this study (Table 2). If Robbins et al. had counted fragments smaller than one-half a valve, which can comprise a significant portion of the species composition in cores (Glover 1982), their estimate of pBSi probably would be greatly improved.

The chemical measurement of BSi in cores could overestimate diatom derived silica if non-diatom amorphous silica was present and was extracted during the analysis for BSi. Failure to account for measure sedimentary BSi from microfossil counts (Robbins et al. 1975) or failure to balance silica budgets in the Great Lakes (Nriagu 1978; Johnson \& Eisenreich 1979) has led to speculation that the silica stored in Great Lakes sediments should be comprised largely of authigenic amorphous cryptocrystalline silicates. Johnson \& Eisenreich (1979) suggested that this mineral was smectite, although their attempts to identify smectite by $\mathrm{X}$-ray diffraction were unsuccessful in lake Superior cores. Digestion of sediments with $0.1 \mathrm{~N} \mathrm{HCl}$ should extract any amorphous alumino-silicates present in the sample (J.E. Mackin, Marine Sciences Research Center, SUNY - Stony Brook, Stony Brook, New York, USA, pers. comm.). If measured BSi was comprised mostly of authigenic amorphous alumino-silicates then BSi concentrations determined following acid digestion should have been significantly less than the BSi concentration determined on raw sediment samples. However, BSi concentrations measured in sediment samples before and after acid/peroxide 
cleaning are comparable (Table 4). It has been shown that although silica can be consumed in the formation of new clay minerals by "reverse weathering" reactions (MacKenzie \& Garrels 1966; Berner 1971; Mackin \& Aller 1984a, 1984b), the quantities of an authigenic alumino-silicate mineral should constitue a very minor fraction of sediments relative to the detrital component. In addition, because of the uniformity in the composition of sediments from the Great Lakes (Thomas 1981), there is no a priori reason to suggest that authigenic aluminosilicates would be more prevalent in the Lake Michigan and Lake Superior cores than in the Lake Ontario and Lake Erie cores. Therefore, it is unlikely that exraction of authigenic minerals during the measurement of BSi can account for this discrepancy between measured $\mathrm{BSi}$ and $\mathrm{pBSi}$.

pBSi could be underestimating measured BSi because not all siliceous components of the microfossil assemblage were included in calculating $\mathrm{pBSi}$. These components include chrysophycean cysts and sponge spicules, which have a large silica content relative to the majority of diatoms (Boucher 1984); and the occasional large, heavily silicified benthic diatom. Cores enumerated for siliceous microfossil abundance in Lake Superior (Stoermer et al. 1985c), Lake Michigan (Glover 1982; E.F. Stoermer \& J.A. Wolin unpubl. data), and the presettlement flora of the Bay of Qunite (Stoermer et al. 1985a) are relatively enriched in benthic diatoms. In most instances,

Table 4. BSi concentration of undigested freeze-dried sediment samples (US) and mean BSi concentration of peroxide/acid cleaned $(A C)$ sediment samples $(n=2)$ at various depths in a core collected from Green Bay, Lake Michigan (C37) in 1985 and the Lake Michigan core collected in 1985.

\begin{tabular}{cccc}
\hline $\begin{array}{c}\text { Depth } \\
(\mathrm{cm})\end{array}$ & $\begin{array}{c}\text { US } \\
\left(\mathrm{mg} \cdot \mathrm{g}^{-1}\right)\end{array}$ & $\begin{array}{c}\text { AC } \\
\left(\mathrm{mg} \cdot \mathrm{g}^{-1}\right)\end{array}$ \\
\hline C37-84 & 181 & $176 \pm 11$ \\
& $6-2$ & 172 & $165 \pm 7$ \\
$12-14$ & 210 & $198 \pm 2$ \\
$18-20$ & 243 & $248 \pm 6$ \\
$28-30$ & 102 & $107 \pm 1$ \\
& $38-40$ & 31 & $52 \pm 4$ \\
& & & \\
$\mathrm{~K} 34-85$ & 141 & $140 \pm 14$ \\
& $0-1$ & 133 & $145 \pm 3$ \\
& $2-3$ & 141 & $146 \pm 21$ \\
& $4-5$ & 38 & $56 \pm 2$ \\
& $8-9$ & 21 & $35 \pm 2$ \\
$12-13$ & 34 & $45 \pm 1$ \\
$20-22$ & 25 & $40 \pm 5$ \\
$28-30$ & 19 & $28 \pm 8$
\end{tabular}


these components are numerically low in abundance and unimportant in terms of the composition of the assemblage, but have the potential of comprising a significant fraction of BSi because of their large silica content.

The discrepancy between chemically measured BSi and the silica predicted from diatoms in the Lake Michigan and Lake Superior cores was partially due to the inability of the regression model (Eq. 1), used to estimate diatom silica content, to account for different degrees of silicification in the diatom assemblages from the more dissolved silica rich Lake Michigan and Lake Superior. If the silica contents of the largest diatoms and, therefore, the most important species in terms of $\mathrm{pBSi}$ are greater than predicted from the regression model then a better correspondance between measured $\mathrm{BSi}$ and BSi determined from diatom silica would be attained.

The results from this study suggest that the measurement of BSi can be a good estimate of diatom silica in sediments. In sediments where chrysophycean cysts, sponge spicules, or benthic diatoms are present, these components must be taken into account in determining microfossil silica because they contain a large silica content relative to the majority of diatoms. In addition, a linear relationship between BSi and diatom abundance should not necesarily be expected because of the size range and thus the silica content of different diatom species present in a core. Because the largest species accounted for significant portions of $\mathrm{pBSi}$, further research on actual silica contents of those species is necessary to refine estimates of pBSi in cores.

\section{Acknowledgements}

I sincerely appreciate the discussion, input and willingness to provide data from my colleagues at the Great Lakes Research Division including C. Campbell, J.P. Kociolek, T.L. Newberry, T.B. Ladewski and J.A. Wolin. J.P. Kociolek and J.A. Wolin provided many of the size measurements for biovolume estimates.

The manuscript was improved through thoughtful and constructive reviews by J.M. Boucher, J.C. Kingston, D.K. Rea, J.A. Robbins, D. Scavia, C.L. Schelske, E.F. Stoermer, and three anonymous reviewers. Financial support was provided by C.L. Schelske and E.F. Stoermer. J.A. Robbins generously provided the cores and ${ }^{210} \mathrm{~Pb}$ dates from Lake Ontario and Lake Erie.

This manuscript is contribution 491 of the Great Lakes Research Division, The University of Michigan, Ann Arbor, MI 48109. 


\section{References}

Bailey-Watts, A.E. 1976. Planktonic diatoms and some diatom-silica relations in a shallow eutrophic Scottish Loch. Freshwater Biology 6: 69-80

Battarbee, R.W. 1973. A new method for estimating absolute microfossil numbers with special reference to diatoms. Limnology and Oceanography 18: 647-653.

Berner, R.A. 1971. Principles of Chemical Sedimentology, McGraw-Hill

Boucher, J.M. 1984. Silica dissolution and reaction kinetics in Southern California Borderland sediments. M.S. thesis, University Southern California, USA

Cheng, D.M.H. \& P.A. Tyler 1973. The effect of diatom populations on silica concentrations of Lakes Sorell and Crescent, Tasmania, and the utilisation of tripton as a source of silica. British Phycological Journal 8: 249-256

Conley, D.J., S.S. Kilham \& E.C. Theriot. Differences in silica content between marine and freshwater diatoms. Limnology and Oceanography (Submitted)

DeMaster, D.J. 1981. The supply and accumulation of silica in the marine environment. Geochimica et Cosmochimica Acta 45: 1715-1732

Digerfeldt, G. 1972. The post-glacial development of Lake Trummen. Regional vegetation history, water level changes and paleolimnology. Folia Limnologica Scandinavia 16: 1-104

Einsele, W. \& J. Grim. 1938. Öber den Kielsäuregehalt planktischer Diatomeen und dessen Bedeutung für einige Fragen ihrer Ökologie. Zeitschrift für Botanik 32: 545-590

Eggimann, D.W., F.T. Manheim \& P.R. Betzer. 1980. Dissolution and analysis of amorphous silica in marine sediments. Journal Sediment Petrology 50: 215-225

Engstrom, D.R. \& H.E. Wright. 1984. Chemical stratigraphy of lake sediments as a record of environmental change. In: E.Y. Haworth \& J.W.G. Lund (Eds) Lake Sediments and Environmental History (pp. 11-67). University of Minnesota Press, Minneapolis, Minnesota USA

Flower, R. 1980. A study of sediment formation, transport and deposition in Lough Neagh, Northern Ireland, with special reference to diatoms. Ph.D. dissertation, New University of Ulster

Gibson, C.E. 1981. Silica budgets and the ecology of planktonic diatoms in an unstratified lake (Lough Neagh, N. Ireland). Internationale Revue der Gesamten Hydrobiologie 66: $641-664$

Gibson, C.E., R.B. Wood, E.L. Dickson, and D.H. Jewson. 1971. The succession of phytoplankton in L. Neagh 1968-70. Internationale Vereinigung für theoretische und angewandte Limnologie 19: 146-160

Glover, R.M. 1982. Diatom fragmentation in Grand Traverse Bay, Lake Michigan and its implications for silica cycling. Ph.D. dissertation, University of Michigan, Ann Arbor, Michigan, U.S.A

Haworth, E.Y. 1980. Comparison of continuous phytoplankton records with the diatom stratigraphy in the recent sediments of Blelham Tarn. Limnology and Oceanography 25: 1093-1103

Hurd, D.C. 1972. Factors affecting solution rate of biogenic opal in seawater. Earth and Planetary Science Letters 15: 411-417

Johnson, T.C., and S.J. Eisenreich. 1979. Silica in Lake Superior: mass-balance considerations and a model for dynamic response to eutrophication. Geochimica et Cosmochimica Acta 43: 77-91

Kilham, P. 1971. A hypothesis concerning silica and the freshwater planktonic diatoms. Limnology and Oceanography 16: 10-18

Leinen, M. 1985. Techniques for determining opal in deep-sea sediments: a comparison of radiolarian counts and X-ray diffraction data. Marine Micropalentology 9: 375-383 
Lisitsyn, A.P. 1971. Basic relationships in distribution of modern siliceous sediments and their connection with climatic zonations. International Geology Review 9: 631-652, 842-865, 980-1004, 114-1130

Lund, J.W.G. 1950. Studies on Asterionella formosa Hass. II. Nutrient depletion and the spring maximum. Journal of Ecology 38: 1-14

Mackin, J.E. and R.C. Aller. 1984a. Dissolved Al in sediments and waters of the East China Sea: Implications for authigenic mineral formation. Geochimica et Cosmochimica Acta 48: 281-297

Mackin, J.E. and R.C. Aller. 1984b. Diagenesis of dissolved aluminum in organic-rich estuarine sediments. Geochimica et Cosmochimica Acta 48: 299-213

MacKenzie, F.T. and R.M. Garrels. 1966. Chemical mass balance between rivers and oceans. American Journal of Science 264: 507-525

Newberry, T.L. and C.L. Schelske. 1986. Biogenic silica record in the sediments of Little Round Lake. Hydrobiologia 143, 293-300

Nriagu, J.O. 1978. Dissolved silica in pore waters of Lakes Ontario, Erie, and Superior sediments. Limnology and Oceanography 23: 53-67

Parker, J.I., and D.N. Edginton. 1976. Concentration of diatom frustules in Lake Michigan sediment cores. Limnology and Oceanography $21: 887-893$

Renberg, I. 1976. Paleolimnological investigations in Lake Prästsjon. Early Norrland 9: 113-159

Robbins, J.A., D.N. Edginton, and J.I. Parker. 1975. Distribution of amorphous, diatom frustule, and dissolved silica in a lead-210 dated core from southern Lake Michigan. In: Radiological and Environmental Research Division Annual Report, Ecology. Argonne National Laboratory, ANL-75-3

Schelske, C.L. and E.F. Stoermer. 1971. Eutrophication, silica and predicted changes in algal quality in Lake Michigan. Science 173: 423-424

Schelske, C.L. and J.C. Roth. 1973. Limnological survey of Lakes Michigan, Superior, Huron and Erie. University of Michigan, Great Lakes Research Division Publication Number 17, $108 \mathrm{pp}$.

Schelske, C.L., E.F. Stoermer, D.J. Conley, J.A. Robbins, and R.M. Glover. 1983. Early eutrophication in the lower Great Lakes: new evidence from biogenic silica in sediments. Science 222: $320-322$

Schelske, C.L., D.J. Conley, and W.F. Warwick. 1985. Historical relationships between phosphorus loading and biogenic silica accumulation in Bay of Quinte sediments. Canadian Journal of Fisheries and Aquatic Science 42: 1401-1409

Schelske, C.L., D.J. Conley, E.F. Stoermer, T.L. Newberry, and C.D. Campbell. 1986. Biogenic silica and phosphorus accumulation in sediments as indices of eutrophication in the Laurentian Great Lakes. Hydrobiologia 143: 79-86

Sicko-Goad, L.M., C.L. Schelske and E.F. Stoermer. 1984. Estimation of intracellular carbon and silica content of diatoms from natural assemblages using morphometric techniques. Limnology and Oceanography 29: 1170-1178

Sommer, U. and H.-H. Stabel. 1983. Silicon consumption and population density changes of dominant planktonic diatoms in Lake Constance. Journal of Ecology 71: 119-130

Stoermer, E.F., J.A. Wolin, C.L. Schelske, and D.J. Conley. 1985a. Postsettlement diatom succession in the Bay of Quinte, Lake Ontario. Canadian Journal of Fisheries and Aquatic Science 42: 754-767

Stoermer, E.F., J.A. Wolin, C.L. Schelske, and D.J. Conley. 1985b. An assessment of ecological changes during the recent history of Lake Ontario based on siliceous algal microfossils preserved in the sediments. Journal of Phycology 21: 257-276

Stoermer, E.F., J.P. Kociolek, C.L. Schelske, and D.J. Conley. 1985c. Siliceous microfossil 
succession in the recent history of Lake Superior. Proceedings of the Academy of Natural Science Philadelphia 137: 106-118

Stoermer, E.F., J.P. Kociolek, C.L. Schelske, and D.J. Conley. 1987. Quantitative analysis of siliceous microfossils in the sediment of Lake Erie's central basin. Diatom Res. 2: 113-134 Strathmann, R.R. 1967. Estimating the organic carbon content of phytoplankton from cell volume or plasma volume. Limnology and Oceanography 12: 411-418

Theriot, E.C. and E.F. Stoermer. 1984. Principle component analysis of Stephanodiscus: Observations on two new species from the Stephanodiscus niagarae complex. Bacillaria 7: $37-58$

Thomas, R.L. 1981. Sediments of the North American Great Lakes. Internationale Vereinigung für theoretische und angewandte Limnologie 21: 1666-1680 